\title{
ANALISIS KEBUTUHAN MAHASISWA PROGRAM STUDI PGSD UAD DALAM MATA KULIAH PEMBELAJARAN TERPADU DI SEKOLAH DASAR
}

\author{
Amaliyah Ulfah \\ FKIP Universitas Ahmad Dahlan Yogyakarta \\ amaliyah.ulfah@pgsd.uad.ac.id
}

\begin{abstract}
Good mastery of integrated learning model is one of important competencies for primary school education students. Without good mastery, they will find it hard to design and do instruction in primary schools that involve a number of fields of study and themes. This study aims at investigating the needs of primary school education students in the course of integrated learning in Elementary school. This is a survey research which used questionnaire to collect the data. The population of this study were 318 primary school education students who took the course. It used proportionale stratified sampling with the number of samples as many as 178 students. The results indicate that the needs of students were related to course materials, including a variety of Elementary school students characteristics, types or models, procedures, and assessment in integrated learning. It is expected that the teaching methods of integrated learning course use direct practice in Elementary school. while the evaluation system is in written form and practice.
\end{abstract}

Keywords: analysis, needs, students, integrated learning

\section{PENDAHULUAN}

Peralihan kurikulum dari KTSP ke Kurikulum 2013 mengubah paradigma pembelajaran di sekolah dasar yang mengharuskan seorang guru juga harus mampu melaksanakan pembelajaran secara terpadu /tematik (Risminawati dan Nurul Fadilah: 2016: 3). Pembelajaran terpadu dapat diartikan sebagai pendekatan pembelajaran yang menghubungkan konsep berbagai mata pelajaran. Melalui pembelajaran terpadu, pembelajaran di sekolah dasar disajikan secara holistik agar pembelajaran menjadi lebih aktif dan bermakna. Oleh karena itu pendekatan pembelajaran terpadu menjadi salah satu aspek penting yang harus dikuasai mahasiswa calon guru sekolah dasar.

Mata kuliah tentang pengajaran memang mendapatkan porsi yang cukup besar di PGSD dan merupakan mata kuliah yang wajib ditempuh oleh mahasiswa calon guru sekolah dasar. Penguasaan pembelajaran terpadu sendiri dapat diperoleh mahasiswa jurusan PGSD melalui salah satu mata kuliah yaitu Pembelajaran Terpadu di Sekolah Dasar. Mata kuliah pembelajaran terpadu merupakan mata kuliah yang membekali mahasiswa dengan pengetahuan dan keterampilan-keterampilan dalam memadukan dan menghubungkan mata pelajaran maupun materi pelajaran di sekolah dasar menggunakan tema-tema. Melalui mata kuliah ini mahasiswa juga dilatih melakukan penilaian di sekolah dasar secara variatif.

Walaupun mata kuliah pembelajaran terpadu sudah diberikan di semester 4, akan tetapi banyak mahasiswa semester atas yang kesulitan melaksanakan pembelajaran terpadu (tematik). Contohnya berdasarkan hasil observasi ketika praktek micro teaching, masih banyak dijumpai mahasiswa yang kurang bisa menghubungkan atau mengaitkan antara mata pelajaran satu 
dengan yang lain dalam satu tema. Mahasiswa juga sering kebingungan bagaimana melakukan apersepsi dalam pembelajaran terpadu. Banyak juga mahasiswa yang tidak bisa menggunakan alokasi waktu dengan baik ketika melaksanakan pembelajaran secara terpadu (rata-rata melebihi waktu yang ditentukan). Selain itu tidak sedikit mahasiswa yang mengeluh kesulitan jika harus menyusun instrument penilaian yang bervariasi dalam pembelajaran terpadu. Kendala-kendala seperti itu juga pernah disampaikan oleh praktisi yang mengampu micro teaching maupun guru ketika melaksanakan magang di sekolah. Hal tersebut sangat disayangkan jika dibiarkan terus menerus. Oleh karena itu mahasiswa PGSD perlu bekal yang cukup bagaimana melaksanakan pembelajaran terpadu di sekolah dasar.

Mata kuliah yang berhubungan dengan pengajaran di sekolah dasar menjadi hal penting yang harus dikaji lagi bagi prodi PGSD. Namun sayangnya selama ini buku ajar atau modul khusus tentang pembelajaran terpadu di sekolah dasar belum pernah dibuat. Bahan ajar memiliki posisi yang sangat penting dalam pembelajaran yaitu sebagai representasi dari penjelasan pendidik di kelas. Namun sebelum menyusun bahan ajar yang baik, sebaiknya perlu dilakukan analisis kebutuhan mahasiswa terlebih dahulu terkait materi atau metode yang harus dikembangkan. Penyusunan bahan ajar yang mempertimbangkan kebutuhan mahasiswa sangat penting dilakukan agar bahan ajar dapat disusun secara lengkap sesuai dengan kebutuhan mahasiswa dan kebutuhan di lapangan. Oleh karena itu penelitian ini perlu dilakukan karena berupaya menggali kebutuhan mahasiswa dalam mata kuliah Pembelajaran Terpadu di Sekolah Dasar.
Analisis kebutuhan dapat diartikan sebagai alat untuk melakukan sebuah perubahan. Menurut Anderson, dkk. Menurut Suharsimi (2008: 56) analisis kebutuhan diartikan sebagai suatu proses yang dilakukan oleh seseorang untuk mengidentifikasi kebutuhan sekaligus menentukan prioritas diantaranya. Sedangkan menurut Kaufman (Witkin, 1984: 6) analisis kebutuhan diartikan sebagai "sebuah gap antara apa itu (what is) dengan apa yang seharusnya (what sould be) dalam bentuk hasil". Dalam bidang pendidikan analisis kebutuhan merupakan proses penting karena melalui kegiatan ini dapat dilakukan sebuah evaluasi pelaksanaan pembelajaran serta memberikan gambaran yang jelas mengenai kesenjangan antara kondisi nyata (riil) dengan kondisi yang diinginkan (harapan) siswa.

Roth (Masaong \& Ansar, 2011) mengkategorikan analisis kebutuhan menjadi dua tipe, yaitu "preparatory (when a product or program is being planned) and retrospective (when the product already exists or the program has been implamented)". Lebih lanjut Hutchinson dan Waters (Nation \& Macalister, 2010: 25) menjelaskan fokus analisis kebutuhan terdiri dari dua hal, yaitu target needs (target kebutuhan) dan learning needs (kebutuhan belajar). Implementasi program atau target kebutuhan dalam penelitian ini yaitu berkaitan dengan kebutuhan dimana pembelajaran terpadu akan diterapkan yaitu di sekolah dasar. Sedangkan kebutuhan belajar atau perencanaan program yaitu kebutuhan mahasiswa PGSD dalam proses pengajaran pembelajaran terpadu dalam perkuliahan. Dua hal pokok ini menjadi penting agar terjadi keselarasan antara 
pemerolehan ilmu dengan kebutuhan di lapangan.

Lebih lanjut Roth (Masaong \& Ansar, 2011) menjelaskan ada enam elemen yang dilakukan dalam proses asesmen kebutuhan pada pendidikan tinggi yaitu: “(1) educational goals or philosophy given as a point departure, (2) need indefication and need prioritization, (3) treatment selection, (4) treatmen implementation, (5) evaluation, and (6) modification and recicle”. Langkah pertama yang dapat dilakukan yaitu menentukan tujuan pengajaran. Langkah kedua yaitu: mengidentifikasi kebutuhan kebutuhan pembelajar kemudian memprioritaskan kebutuhan yang paling utama. Langkah selanjutnya yaitu memilih jenis penanganan atau solusi. Langkah keempat yaitu implementasi penanganan. Kemudian melakukan evaluasi dan modifikasi.

Menurut Subroto, dkk (2005: 16) pembelajaran terpadu yaitu pembelajaran yang diawali dengan suatu pokok bahasan atau tema tertentu yang dikaitkan dengan pokok bahasan lainnya. Jika dikaitkan dengan tingkat perkembangan siswa, pembelajaran terpadu merupakan pendekatan pembelajaran yang berangkat dari teori pembelajaran yang menolak sistem drill sebagai dasar pembentukan pengetahuan (Prabowo, 2000). Trianto (2012: 69) juga menjelaskan prinsip utama yang harus dikembangkan dalam pembelajaran terpadu adalah Developmentally Approprite Practice (DAP), yang maksudnya pembelajaran harus disesuaikan dengan tingkat perkembangan siswa seperti kognitif, minat, emosi dan bakat.

Jadi dapat disimpulkan pembelajaran terpadu yaitu pendekatan pembelajaran yang menghubungkan konsep berbagai mata pelajaran dalam satu tema agar siswa dapat mengkonstruksi pengetahuannya sendiri melalui interaksi dengan lingkungan. Pelaksanaan pembelajaran terpadu harus memperhatikan tingkat perkembangan dan kebutuhan siswa serta lebih menekankan keterlibatan anak dalam proses pembelajaran sehingga siswa dapat memperoleh pengalaman langsung.

Mata kuliah pembelajaran terpadu di SD merupakan salah satu mata kuliah yang penting diajarkan bagi calon guru sekolah dasar. Hal ini karena penguasaan pembelajaran terpadu dapat mendukung salah satu kompetensi yang harus dikuasai oleh seorang guru yaitu kompetensi pedagogik. Menurut UU RI No. 14 Tahun 2005 kompetensi pedagogi adalah kemampuan pemahaman terhadap peserta didik, perancangan dan pelaksanaan pembelajaran, evaluasi hasil belajar, dan pengembangan peserta didik untuk untuk mengaktualisasikan berbagai potensi yang dimilikinya.

Undang-undang telah menuliskan dengan jelas bahwa seorang guru harus bisa merancang dan melaksanakan pembelajaran dengan baik. Pembelajaran terpadu merupakan salah satu pendekatan pembelajaran yang harus dikuasai oleh guru sekolah dasar sesuai dengan aturan dalam Kurikulum 2013. Namun karena banyaknya kelas di PGSD, dengan pengajar/ dosen yang berbeda-beda dan gaya mengajar yang berbeda menjadikan kemampuan mahasiswa juga beragam. Pada akhirnya ketika mata kuliah micro teaching/ magang terapan di semester atas banyak ditemukan permasalahan terkait praktek pembelajaran terpadu di SD. 


\section{METODE PENELITIAN}

Penelitian ini merupakan penelitian deskriptif dalam bentuk survey. Penelitian ini dilaksanakan di Kampus 5 Universitas Ahmad Dahlan, Jl. Ki Ageng Pemanahan No 19 Yogyakarta. Teknik pengumpulan data yang digunakan yaitu angket. Populasi dalam penelitian ini adalah mahasiswa S1 PGSD semester 5 kelas A, B, C, D, E, F, dan G sebanyak 318 orang. Teknik pengambilan sampel dilakukan secara proportionale stratified sampling. Penentuan jumlah sampel menggunakan rumus Slovin dengan taraf signifikasi 5\% sehingga sampel penelitian yang digunakan yaitu sebanyak 178 mahasiswa.

\section{HASIL DAN PEMBAHASAN}

\section{Peran Mata Kuliah Pembelajaran Terpadu di SD}

Pernyataan angket pertama dan kedua berkaitan dengan peran mata kuliah pembelajaran terpadu di sekolah dasar bagi mahasiswa. Berdasarkan hasil angket pertama diperoleh informasi jika seluruh mahasiswa PGSD (100\%) sepakat Mata Kuliah Pembelajaran Terpadu sangat penting dipelajari. Adapun alasan mahasiswa sangat beragam, antara lain: Mata Kuliah Pembelajaran Terpadu di SD dapat memperjelas mahasiswa ketika akan melaksanakan pembelajaran terpadu di sekolah dasar, melalui Mata Kuliah Pembelajaran Terpadu mahasiswa dapat mengetahui komponen atau RPP K13 dan cara menyusunnya, melalui mata kuliah pembelajaran terpadu mahasiswa dapat berlatih menggabungkan beberapa mata pelajaran dalam satu tema, mahasiswa dapat belajar menentukan rencana pembelajaran yang menarik, dan mahasiswa dapat terlatih keterampilannya dalam melaksanakan pembelajaran tematik.

Pernyataan angket kedua memberi informasi 167 mahasiswa $(93,8 \%)$ sepakat jika mata kuliah pembelajaran terpadu dapat memberi contoh implementasi pembelajaran terpadu di sekolah dasar. Alasan mahasiswa secara umum karena melalui mata kuliah tersebut mahasiswa mempunyai gambaran tentang pembelajaran di SD sehingga dapat mengimplementasikan dengan baik. Selain itu mahasiswa juga bisa memperoleh informasi tentang kesulitan-kesulitan dan pemecahan masalah terkait pembelajaran terpadu. Namun ada 11 mahasiswa $(6,2 \%)$ yang tidak setuju jika mata kuliah pembelajaran terpadu dapat memberi contoh implementasi pembelajaran terpadu di sekolah dasar. Hal ini karena mahasiswa seringkali di lapangan menemui beberapa guru yang belum menggunakan RPP tematik walaupun sekolahnya sudah mengimplementasikan K13.

\section{Kebutuhan Mahasiswa Terkait Materi}

Materi pengajaran mata kuliah pembelajaran terpadu secara garis besar dapat dikelompokkan menjadi 7 bagian yaitu: 1) Konsep dasar pembelajaran terpadu, 2) Karakteristik siswa SD, 3) Jenis/ model pembelajaran terpadu, 4) Prosedur pembelajaran terpadu, 5) Perangkat pembelajaran terpadu, 6) Pengembangan RPP. dan pembelajaran terpadu, dan 7) Penilaian pembelajaran terpadu. Dari ketujuh garis besar materi, mahasiswa kemudian diminta memilih materi sesuai kriteria sangat dibutuhkan, cukup dibutuhkan, dan kurang dibutuhkan. Hasil penilaian mahasiswa dapat dijelaskan pada Tabel 1. 
Tabel 1. Kebutuhan Mahasiswa Terkait Materi Pembelajaran Terpadu

\begin{tabular}{cccc}
\hline Materi & Sangat dibutuhkan & Cukup dibutuhkan & Kurang dibutuhkan \\
\hline $\mathbf{1}$ & $69,7 \%$ & $30,3 \%$ & - \\
$\mathbf{2}$ & $72 \%$ & $28 \%$ & - \\
$\mathbf{3}$ & $73 \%$ & $27 \%$ & - \\
$\mathbf{4}$ & $70,2 \%$ & $29,8 \%$ & - \\
$\mathbf{5}$ & $50 \%$ & $47 \%$ & $3 \%$ \\
$\mathbf{6}$ & $68 \%$ & $32 \%$ & - \\
$\mathbf{7}$ & $71,3 \%$ & $28,7 \%$ & - \\
\hline
\end{tabular}

Berdasarkan hasil Tabel 1, menurut mahasiswa materi yang masuk kategori sangat dibutuhkan dengan prosentase tinggi yaitu karakteristik siswa SD (72\%), jenis/ model pembelajaran terpadu $(73 \%)$, prosedur pembelajaran terpadu $(70,2 \%)$, pengembangan RPP dan penilaian pembelajaran terpadu $(71,3 \%)$. Sedangkan materi yang cukup dibutuhkan dengan prosentase tertinggi menurut mahasiswa yaitu perangkat pembelajaran terpadu (47\%). Selain itu ada juga sebesar 3\% mahasiswa yang memilih materi perangkat pembelajaran terpadu sebagai materi yang kurang dibutuhkan. Materi perangkat pembelajaran terpadu mendapatkan prosentase cukup tinggi pada kategori cukup dibutuhkan dan kurang dibutuhkan karena mahasiswa pada umumnya sudah memiliki pengetahuan tentang perangkat pembelajaran dalam mata kuliah di semester sebelumnya. Dari hasil penilaian mahasiswa juga diperoleh informasi terkait materi lainnya yang sebaiknya juga dipelajari maupun diperdalam dalam Mata Kuliah Pembelajaran Terpadu di SD antara lain:

1) Perumusan tujuan pembelajaran yang lebih mendalam

2) Pengembangan model pembelajaran terpadu

3) Pemilihan atau perancangan media pembelajaran dalam pembelajaran terpadu
4) Integrasi kearifan lokal atau karakter dalam pembelajaran terpadu

Pemberian kesempatan kepada mahasiswa untuk menentukan sendiri materi yang dibutuhkan mempunyai arti yang sangat penting karena dapat menunjang keberhasilannya dalam pembelajaran. Hal ini sesuai dengan pendapat Oxfor (Dahnilsyah, 2011: 91) yang menyatakan apabila siswa diberi kesempatan untuk memilih sendiri materi, menentukan tujuan, dan arah proses pembelajaran sesuai yang mereka inginkan, maka mereka akan mampu dan berusaha lebih keras mencapai tujuan belajar mereka.

\section{Kebutuhan Mahasiswa Terkait Metode Pengajaran Pembelajaran Terpadu}

Bagian ini menjelaskan tentang metode apa yang menjadi kebutuhan mahasiswa pada mata kuliah pembelajaran terpadu. Penulis memberikan alternatif pilihan metode pengajaran dalam mata kuliah pembelajaran terpadu yaitu melalui ceramah bervariasi, demonstrasi, atau praktek langsung di SD. Selain itu penulis juga memberikan kebebasan bagi mahasiswa jika ingin menuliskan metode yang menurut mereka lebih sesuai. Hasil angket dapat dijelaskan pada Tabel 2. 
Tabel 2. Kebutuhan Mahasiswa Terkait Metode Pengajaran

\begin{tabular}{lcc}
\hline \multicolumn{1}{c}{ Metode } & Jumlah mahasiswa & Persentase \\
\hline Ceramah bervariasi & 14 & $7,8 \%$ \\
\hline Demonstrasi & 58 & $32,6 \%$ \\
\hline Praktek langsung di SD & 80 & $45 \%$ \\
\hline Semua metode digabungkan & 26 & $14,6 \%$ \\
\hline
\end{tabular}

Berdasarkan Tabel 2 dapat diketahui sebagian besar mahasiswa (45\%) menginginkan metode pengajaran terpadu dengan praktek langsung di SD. Alasan mahasiswa secara umum karena mahasiswa dapat secara langsung mempraktekkan bagaimana mengajar pembelajaran terpadu tidak hanya sekedar teori sehingga harapannya dapat memperoleh pengalaman yang nyata. Selain metode praktek, tidak sedikit juga mahasiswa yang menghendaki metode pengajaran pembelajaran terpadu dengan demonstrasi $(32,6 \%)$. Demonstrasi dilakukan dengan cara dosen mepraktekkan contoh/ konsep kemudian mahasiswa ikut berlatih mempraktekkan. Alasan mahasiswa memilih metode ini karena metode ini lebih mudah diingat dan mudah diulang-ulang jika belum paham. Menariknya ada 7,8\% responden lainnya yang memilih metode pembelajaran terpadu lebih sesuai jika menggunakan ceramah bervariasi.

Selain metode pengajaran, penulis juga berusaha menganalisis kebutuhan mahasiswa terkait media dan modul pembelajaran terpadu. Berdasarkan hasil angket 145 mahasiswa $(81,5 \%)$ sepakat jika mata kuliah pembelajaran terpadu perlu menggunakan media pembelajaran. Adapun media yang diinginkan mahasiswa antara lain: Buku guru dan buku siswa K13, RPP edisi revisi terbaru, artikel terkait pembelajaran terpadu untuk menambah wawasan, media konkret dan alat peraga edukatif lainnya yang bisa digunakan dalam pembelajaran terpadu. Sedangkan responden lainnya $(18,5 \%)$ memilih mata kuliah tersebut tidak memerlukan media. Alasannya karena fokus mata kuliah pembelajaran terpadu yaitu mahasiswa mampu menyusun RPP terpadu dan praktek melaksanakannya sehingga penggunaan media tidak terlalu penting.

Untuk modul, sebanyak 140 mahasiswa $(78,6 \%)$ setuju mata kuliah pembelajaran terpadu membutuhkan modul atau bahan ajar. Alasan mahasiswa sangat beragam yaitu agar materi lebih mudah mempelajari, materi tidak tercecer dan terarah, memudahkan mahasiswa mencari referensi, dapat digunakan sebagai sebagai panduan, dan dapat dipelajari lagi ketika sudah lulus. Sedangkan responden lainnya kurang setuju jika ada modul dalam pembelajaran terpadu karena dinilai akan menambah biaya perkuliahan.

\section{Kebutuhan Mahasiswa Terkait Sistem Evaluasi}

Selanjutnya bagian ini akan mengulas kebutuhan mahasiswa terkait penilaian atau asesmen. Penilaian dalam mata kuliah pembelajaran terpadu yang ditawarkan ada 3 bentuk yaitu dalam tertulis, prakter, tertulis dan praktek. Hasil angket dapat dilihat pada Tabel 3. 
Tabel 3. Kebutuhan Mahasiswa Terkait Sistem Evaluasi

\begin{tabular}{lcc}
\hline Sistem evaluasi & Jumlah Mahasiswa & Persentase \\
\hline Tertulis & 17 & $9,5 \%$ \\
\hline Praktek & 39 & $22 \%$ \\
\hline Tertulis dan praktek & 122 & $68,5 \%$
\end{tabular}

Berdasarkan Tabel 3 dapat disimpulkan sebagain besar mahasiswa menginginkan sistem penilaian dalam pembelajaran terpadu secara tertulis dan praktik. Menurut Alimuddin (2014: 29) penilaian praktik adalah penilaian yang menuntut respon berupa keterampilan melakukan suatu aktivitas atau perilaku sesuai dengan tuntutan kompetensi. Penilaian praktik dilakukan dengan mengamati kegiatan peserta didik dalam melakukan sesuatu. Menurut mahasiswa dengan sistem penilaian tersebut dapat lebih mengetahui tingkat pengetahuan masing-masing, lebih tahu bagaimana mengajarkan pembelajaran terpadu, lebih bermakna karena dapat mengetahui letak kesalahan ketika praktek, dan lebih adil karena untuk bisa mendapatkan hasil yang baik mahasiswa harus benar-benar paham teori dan juga prakteknya.

Penilaian praktik yang dimaksud dalam mata kuliah pembelajaran terpadu adalah mahasiswa harus bisa mempraktikkan beberapa keterampilan dasar mengajar dan dapat menunjukkan kemampuan mengajar menggunakan salah satu model pembelajaran terpadu. Praktek mengajar mahasiswa dilaksanakan secara kelompok (team teaching), namun penilaiannya secara individu. Langkah yang dilakukan dalam penilaian praktik yaitu: 1) membagi mahasiswa menjadi beberapa kelompok (maksimal 4 anak), 2) menentukan indikator penilaian berdasarkan kompetensi yang akan dinilai, 3) membagi tema/ sub tema dan kelas yang akan dipraktikkan, 4) menyusun RPP yang akan dipraktikkan, 5) praktik mengajar, 6) evaluasi praktik pengajar.

\section{Solusi yang Ditawarkan}

Solusi yang dapat ditawarkan terkait kebutuhan mahasiswa terhadap materi pengajaran yaitu dengan memberikan porsi belajar yang cukup untuk materi-materi yang sangat dibutuhkan dan mengurangi materi yang tidak terlalu dibutuhkan seperti perangkat pembelajaran terpadu. Selain itu penulis bersama tim dosen mata kuliah yang sama juga akan menambahkan materi lain yang memang dibutuhkan mahasiwa seperti penyusunan tujuan pembelajaran yang benar dan pengintegrasian kearifan lokal atau karakter dalam pembelajaran terpadu.

Selama ini metode pengajaran yang digunakan dalam mata kuliah pembelajaran terpadu yaitu demontrasi dan praktek di kelas. Agar pembelajaran terpadu lebih bermakna, dosen bersama tim akan mendiskusikan, mengkaji, dan mengupayakan agar mahasiswa dapat praktek secara langsung di SD walaupun hanya 1 atau 2 kali. Hal ini karena sulitnya mengatur waktu perkuliahan 2 sks dengan praktek di lapangan yang membutuhkan waktu yang lama. Terkait kebutuhan mahasiswa terhadap media pembelajaran, penulis akan mengusulkan agar perpustakaan juga dilengkapi dengan Buku Guru dan Buku Siswa K13 yang lengkap. 
Penulis bersama tim dosen juga akan segera menyusun modul pembelajaran terpadu agar lebih memudahkan mahasiswa dalam belajar.

Selanjutnya terkait sistem evaluasi pembelajaran sudah sesuai karena selama ini system evaluasi yang digunakan adalah tertulis dan praktek. Tertulis untuk Ujian Tengah Semster (UTS) dan praktek untuk Ujian Akhir Semster (UAS).

\section{SIMPULAN}

Secara garis besar dapat disimpulkan kebutuhan mahasiswa PGSD UAD dalam mata kuliah Pembelajaran Terpadu di SD dari segi materi yang sangat dibutuhkan yaitu Karakteristik siswa SD, Jenis atau model pembelajaran terpadu, Prosedur pembelajaran terpadu, dan Penilaian pembelajaran terpadu. Metode pengajaran mata kuliah pembelajaran terpadu lebih sesuai dengan praktek langsung di SD. Sistem evaluasi mata kuliah pembelajaran terpadu sebaiknya dalam bentuk tertulis dan praktik. Ketiga aspek di atas sangat relevan dengan upaya pemenuhan kebutuhan mahasiswa, yakni dari segi materi yang lebih runut, pemilihan metode yang lebih tepat, dan sistem penilaian yang sesuai.

\section{DAFTAR PUSTAKA}

Alimuddin. (2014). Penilaian dalam Kurikulum 2013. Disampaikan pada Seminar Nasional Pendidikan Karakter di Gedung SCC Palopo pada Sabtu, 03 Mei 2014.

Dahnilsyah. (2011). "Analisis Kebutuhan dan Minat Mahasiswa pada Mata Kuliah Keterampilan Berbicara di Program Studi Bahasa Inggris, FKIP, Universitas Riau”, dalam Jurnal Bahasa, Vol. 6, No. 1.

Masaong, A. K., \& Ansar. (2011). Manajemen Berbasis Sekolah. Malang: Sentra Media.

Nation, I., \& Macalister, J. (2010). Language Curriculum Design . London: Routledge Taylor and Francis Group.

Prabowo. (2000). Pembelajaran Fisika dengan Pendekatan Terpadu dalam Menghadapi Perkembangan IPTEK Milenium III. Seminar dan Lokakakarya Jurusan Fisika FMIPA UNESA bekerja sama dengan Himpunan Fisika Indonesia (HFI). Surabaya: UNESA.

Risminawati dan Nurul Fadilah. 2016. "Persepsi Guru Terhadap Implementasi Pembelajaran Tematik Integratif Kurikulum 2013 di SD Muhammadiyah 24 surakarta". Jurnal Profesi Pendidikan Dasar. Vol. 3, No. 1 juli 2016. [versi online] http://journals.ums.ac.id/index.php/ppd/article/view/2604. Diakses tanggal 12 Juli 2017.

Subroto, dkk. (2005). Materi Pokok Pembelajaran Terpadu. Jakarta: Universitas Terbuka.

Suharsimi. (2008). Dasar-Dasar Evaluasi Pendidikan. Jakarta: Bumi Aksara. 
Trianto. (2012). Model Pembelajaran Terpadu. Jakarta: PT Bumi Aksara.

UU RI No. 14 Tahun 2005 tentang Guru dan Dosen.

Witkin. (1984). Assessing Needs in Education and Social Programs. San Francisco: JosseyBass Publisher. 